The paper has been accepted for publication in the British Journal

of Management in Dec. 2014!

Changing Business Models

\title{
CHANGING BUSINESS MODELS AND EMPLOYEE REPRESENTATION IN THE AIRLINE INDUSTRY: A COMPARISON OF BRITISH AIRWAYS AND DEUTSCHE \\ LUFTHANSA
}

\section{INTRODUCTION}

In recent years, the notion of business models has gained momentum in management research (Baden-Fuller et al., 2010; Zott, Amit and Massa, 2011). In this debate, scholars have also discussed barriers to changing the business model of existing firms. Several barriers have been identified, such as cognitive lock-ins (Chesbrough and Rosenbloom, 2002). The institutional environment of market economies in which firms operate has not yet been discussed as a barrier and so is identified as a research gap in the debate on business models (Zott and Amit, 2013). Whereas the institutional framework of market economies such as the United Kingdom (UK) provides a high degree of flexibility to firms, the framework of market economies such as Germany provides a substantially lower degree of flexibility (Crossland and Hambrick, 2011; Hall and Soskice, 2001). We investigate how business model changes in firms in the UK and Germany are affected by the influence of employee representation. This employee representation has been discussed in recent work on strategic management as a potential constraint on strategic choice, which accounts for the differential in flexibility provided to firms in both the aforementioned countries (Fiss and Zajac, 2004).

We selected the aviation industry because it is a globalised industry in which established companies from different countries face similar challenges, particularly the challenge presented by low cost carriers (LCCs). Since the mid-1990s, the European aviation industry has undergone a massive transformation. The traditional business model of full service carriers (FSCs) has been challenged by LCCs. Hence, FSCs face strong pressures to reconsider their traditional business 
Changing Business Models

models based purely on differentiation and move them, at least to some extent, in the direction of the LCC model (Bamber et al., 2009; Delfmann et al., 2005).

This paper analyses whether, and the extent to which, two FSCs in two different countries (BA in the UK and LH in Germany) have adopted elements of the LCC model, and the extent to which this process has been influenced by employee representation. There have been no systematic comparisons of the strategic reactions of FSCs, which are embedded in different institutional frameworks, to the low cost pressure exerted by LCCs in the aviation industry. Hence, we propose a systematic comparison of two leading FSCs and their strategic responses to the emergence of LCCs, originating from contrasting market economies, the UK and Germany. Our analysis focuses on the following two questions:

1. To what extent have the selected FSCs, embedded in institutional frameworks that differ in their degree of flexibility, changed their business model in reaction to the low cost pressure exerted by LCCs?

2. To what extent have exogenous institutional factors, including the employee representation regime, affected business model changes?

The paper is structured as follows. First, we distinguish between strategy and the business model concept and discuss recent work on strategic management which has considered the effect of institutions on strategic choice. Second, we outline our methodological approach. Third, we present the findings of our two case studies. Finally, we discuss the theoretical implications of our findings.

Insert Table 1 about here 
Changing Business Models

\section{THEORETICAL BACKGROUND}

\section{Strategy and the Recent Debate on Business Models}

The adoption of low cost practices has been described in several management publications as a strategy based on the choice to compete on price (Barrett, 2004; Collis, 1991). Porter's typology of cost leadership and differentiation strategy is based in part directly on the example of low cost airlines such as Southwest Airlines (Porter, 1996). However, in recent years, a debate has emerged regarding business models (Bock et al., 2012; Miozzo et al., 2012; Patzelt, zu KnyphausenAufsess and Nikol, 2008). Low cost practices in the airline industry have also been described as a new business model (Alamdari and Fagan, 2005; Hunter, 2006). In the following we conceptualise the difference between the concepts of strategy and business model and outline why, for the analysis of the reactions of FSCs towards the emergence of LCCs, the application of the business model concept is more appropriate.

We refer to Zott and Amit (2008) and their distinction between product market strategy and business model. They understand product market strategy, 'as a way in which a firm chooses to position itself against competitors in its addressable market spaces' (ibid: 3). They define a business model as 'a template that depicts the way the firm conducts its business' (Zott and Amit, 2013: 404) and as 'a structural template of how a focal firm transacts with customers, partners, and vendors; that is, how it chooses to connect with factor and product markets' (Zott and Amit, 2008: 5). The strategy and business model concept differ regarding the unit of analysis: while the unit of analysis of strategy is the firm, the business model's unit of analysis is the focal firm and its exchange partners. An important implication of their distinction between the two concepts is that firms may pursue the same strategy with different business models. Qatar Airways and Emirates, for instance, both pursue a differentiation strategy, but differ in terms of how they 
Changing Business Models

transact with exchange partners to deliver the products (i.e., high-service flights in certain markets) needed for this strategy: while Qatar joined a global airline alliance (Oneworld), Emirates prefers a 'go-it-alone' approach. Hence, their business models differ significantly.

Amit and Zott do not specify their categories of business model actors (customers, partners, and vendors). While the categorisation of 'customers' and 'vendors' is rather straightforward, the categorisation of 'partners' is less clear. In a recent publication, Zott and Amit refer to potential business model partners more generally as external stakeholders to which an organization is linked (2013: 404). This suggests that the category of 'partner' should be interpreted more broadly and includes all stakeholders other than customers and vendors that are able to connect the focal firm with factor and product markets. Such stakeholders are suppliers, alliance partners, the state (e.g., by providing subsidies) and employee representatives (particularly trade unions).

Zott and Amit (2013) see their conceptualisation of business models as broadly consistent with the emergent business model literature and refer in this respect to the work of CasadesusMasanell and Ricart (2010). The latter authors conceptualise business models as being composed of managerial choices regarding how the company should operate and the implementation of these choices. The authors distinguish three types of choice: (1) policy choices affecting all aspects of the company's operations; (2) asset choices relating to tangible assets, and (3) governance choices relating to contractual arrangements that grant decision rights over the company's policies or assets. We see this framework as consistent with Amit and Zott's conceptualisation of business models, on the condition that choices and their implementation do not relate to the positioning of firms against competitors ${ }^{1}$. Firms have to make choices regarding transaction partners with which to conduct their business; these can be policy, asset or governance choices. 
Changing Business Models

For the purpose of this paper, namely to systematically analyse the responses of FSCs to the emergence of LCCs, we deem the business model concept more suitable than that of strategy. In order to match the cheap fares (product market strategy) of LCCs on certain routes, it might be possible for FSCs to use profits made on long-haul flights to cross-subsidise flights which directly compete with LCCs or receive state subsidies. However, it is less certain whether FSCs are also able to emulate the way LCCs conduct their business (business model), for example, by not only becoming a low fare but also a low cost carrier, because this would require major concessions from their transaction partners (e.g., employee representatives).

Some barriers to business model change in established companies have been discussed. Managers might be reluctant to experiment with new business models that threaten the traditional configuration of assets and processes (Amit and Zott, 2001). Chesbrough and Rosenbloom (2002) highlight cognitive barriers. Firms are guided by a dominant logic that strongly influences information that is considered relevant. Such cognitive constraints may result in firms ignoring all business opportunities that require significant innovations in their business model. The significant barriers to business model change in established companies raise the question whether established companies can change their business model at all.

Thus far, business model scholars have not yet explored the constraining nature of national institutions as an obstacle to business model change. The only study that broaches this issue is that of Froud et al. (2009). However, their study does not investigate how proposed business model changes are hindered by existing national institutions, but shows how institutional changes forced the BBC to adapt their business model. Zott and Amit (2013) have identified the influence of the environment on business models as a topic which is underexplored and deserves more attention (ibid.: 407). This implies that, depending on the environment in which companies are embedded, 
Changing Business Models

their business model, and changes therein, might be shaped by the respective environment in different ways.

\section{Strategic Management, Institutions and Managerial Discretion}

Until recently, strategic management scholars have paid little attention to the potentially limiting effect of national institutions on the strategic leeway of firms. Only recently has the concept of 'managerial discretion' been evaluated and tested at the national level, by Crossland and Hambrick (2007). They draw on economic sociology to argue that there are systemic differences between nations regarding behaviours (Hall and Soskice, 2001; Whitley, 1999). Building on this tradition, they compare firms in countries with institutional environments which vary widely in the degree to which they constrain managerial discretion. Crossland and Hambrick (2007; 2011) show that national institutions shape managerial discretion. They reveal that countries such as the UK have institutional frameworks that give executives a high level of discretion. Given the dispersed ownership structures in these countries, managerial discretion is usually not constrained by stockholders. Board governance, employment and legal institutions strengthen the role of executives; board governance structures allow CEOs to influence decisions substantially. Employment institutions hardly constrain large-scale layoffs. In countries such as Germany, executives have considerably less discretion. Given the more concentrated ownership structure, they usually have to deal with powerful shareholders. Board governance, employment and legal institutions also limit their discretion. Executives need to consult employee representatives for major decisions, given their participation on company supervisory boards. Works councils are able to impede layoffs. Managerial discretion is further constrained by the civil law tradition, which gives more power to other stakeholders. 
Changing Business Models

Trade unions are another factor, which is discussed in the 'varieties of capitalism' debate (Bamber et al., 2009; Streeck, 1997) as having an influence on management's latitude of action. In countries such as the UK, the influence of unions is quite limited. In countries such as Germany, trade unions have significant strength in many industries, because many employee representatives are union members and sit on supervisory boards, as a result of governance institutions. This institutional argument complements the work of Crossland and Hambrick (2007) because, in core industrial sectors, the strong position of trade unions in Germany constrains managerial discretion.

Other recent works in the field of strategic management also support the notion that national institutions influence managerial discretion. Siegel and Larson (2009) show that labour market institutions in the respective countries affect the human resource practices of a multinational corporation that can be adopted by its subsidiaries. Subsidiaries performed better in countries with employer-friendly labour market institutions; however, managers in countries with more constraining institutions were able to align practices with the institutional environment, and to improve the performance of subsidiaries. Peteraf and Reed $(2007 ; 2008)$ show that the institutional environment before deregulation constrained managerial choice. They also demonstrate that, when the discretion of managers is constrained in one area, they compensate in another area that is less constrained. To summarise, recent strategic management studies show that institutions have the potential to significantly limit managerial discretion.

\section{METHODOLOGY}

We apply a comparative case study design (Eisenhardt, 1989) to analyse whether, and the extent to which, BA and LH have changed their business models in response to the LCC challenge, and how national institutions have influenced changes in their business models. In terms of 
Changing Business Models

Langley's (1999) model of generic strategies of sense-making for the analysis of process data, we apply a mixture of 'narrative' and 'synthetic' sense-making methods when comparing our two cases. Related to the former approach, we collected dense process (interview and secondary) data, which provide deep insights into similarities and differences of meanings, stories and mechanisms for business model changes in each airline. Related to the latter, and based on the strategic management literature, we also define 'clear process boundaries' in the form of business model categories, provide indicators and compare typical sequences of business model changes for each case over time.

The research setting is the passenger airline sector, because this is a globalised industry in which established companies from different countries face similar challenges. The level of competition in this industry, particularly in the form of LCCs, has increased tremendously. The traditional business models have come under considerable pressure. Therefore, the industry is ideally suited for analysing how established companies change their business model when under pressure.

BA and LH have been selected as case studies because they represent traditional FSCs and are located in contrasting types of market economies. The UK and Germany represent market economies where managerial discretion varies significantly (Schneider and Paunescu, 2012).

Several institutions have been discussed as having an influence on managerial discretion. We do not consider the effect of ownership structures on business model change, because LH has a dispersed ownership structure (Lufthansa, 2010). The management's leeway can thus hardly be constrained by shareholders. Another commonality between LH and BA is that, in both cases, trade unions negotiate with the company and not with an employer association. Nevertheless, German unions can be expected to be more influential than in the UK, because they are involved 
Changing Business Models

in the LH supervisory board through employee representatives. Our analysis investigates the extent to which the position of employee representatives, which is potentially strengthened by institutions in the areas of collective bargaining, board governance, law and employment, has influenced changes in the respective business models ${ }^{2}$.

In order to evaluate the business models, we refer to the business model definition of Amit and Zott (2008) discussed above. Furthermore, we argue that firms have to make choices in relation to their exchange partners, and implement them to conduct their business. We refer to the three types of choices outlined by Casadesus-Masanell and Ricart (2010), i.e., policy, asset and governance choices, firms have to make to conduct their business when analysing the business models of the two airlines.

As we aim to evaluate the extent to which BA and LH have adopted the LCC model, we formulate an ideal type for this model: a small divergence from the ideal type indicates a farreaching adoption of the LCC model. We build subcategories of the three categories of choices and, based on the review of the literature, we identify the key features of a 'pure' LCC and the exchange partners with which the firm potentially transacts to organise these features, as shown below (Airscoop, 2011; Alamdari and Fagan, 2005; Casadesus-Masanell and Ricart, 2010; HalesDutton, 2003; Hunter, 2006; Malighetti, Paleari and Redondi, 2009). The potential type of exchange partner is included in the brackets.

Policy choices: no alliances with airlines (partner/company); secondary airports subsidising their flights (partner/company or state); low average labour costs (partner/employee representatives); basic education and training of employees (partner/employee representatives); low recruitment standards (partner/employee representatives), and the foundation of an LCC 
(partner/company). We included the latter subcategory because the launch of an LCC indicates a partial adoption of this model.

Asset choices: limited variety of aircraft models and standardised fleet (partner/vendors).

Governance choices: high percentage of leased aircraft (partner/company), low impact of collective agreements on policy choices (partner/employee representatives).

The data collection was based on multiple sources for triangulation purposes (Jick, 1979). We conducted 23 semi-structured interviews between June 2010 and May 2013; among the interviewees were senior managers and trade unionists directly involved in negotiations between labour and management. We also conducted interviews with executives of competitors of LH and BA, as well as other industry experts, to improve the internal validity of the study (see Table 2). We asked whether our interviewees regarded LCCs as competitors and how they reacted to this new competition. We focused on the business model categories outlined above, in particular the changes therein, and the reasons for these changes.

Insert Table 2 about here

Furthermore, we collected secondary data in the form of annual reports (BA: 2003 to 2012; LH: 2003-2012) and newspaper articles. ${ }^{3}$ The use of annual reports is well-established in strategy research (Bowman, 1978). The analysis of business press articles has increased in management research in recent years (Hellgren, et al., 2002; Decker and Lange, 2013). The secondary data analysis was carried out on material dating back to 1993, after the European Union had introduced three 'packages' to liberalise air transport, and ended in March 2013. We structured our secondary data analysis into two phases; in the first phase, we analysed a wide range of newspapers from the 
time period $1993-2005^{4}$. To conduct this analysis, one of the authors visited an archive, the Hamburgisches Welt-Wirtschafts-Archiv (HWWA), which was dissolved in 2006. The advantage over online research was that articles from quality newspapers (quality as defined by the HWWA) were structured according to companies. In this process, we collected 980 pages of archival data about BA and LH. In the second phase (2006-2013), we focused on four quality newspapers, two for each airline, which had proved most relevant for BA and LH in the period from 1993-2005 (The Financial Times and the Guardian for BA, and the Frankfurter Allgemeine Zeitung and the Wirtschaftswoche for LH), by conducting a Nexis search for articles with British Airways (or the abbreviation BA) or Lufthansa in the headline. In total, we collected 1,732 pages of data for BA and LH. The analysis of the archival data was guided by the aforementioned business model categories. After reading the secondary data, we selected the sections of the newspaper articles that were relevant for one or more of the business model categories and copied and pasted them into a document. Date, source and assigned business model category(ies) were stated in brackets at the end of each section pasted into the documents. This process enabled us to identify changes in business model categories and recurrent patterns.

We also engaged in data triangulation. In an interview at $\mathrm{LH}$, for instance, we asked about the company's motivation when setting up the LCC Germanwings. The interviewee corroborated the result of the secondary data analysis, namely that its foundation was a deliberate attempt to circumvent the company's constraining collective agreement with the union. Conversely, we used the collected secondary data to corroborate the findings of the interviews. For instance, the secondary data analysis corroborated the impression of interviewees that BA had earlier and more radically reduced the variety of aircraft models (for a detailed account of the data analysis see table $3)$. 


\section{Insert Table 3 about here}

The basic elements of our case analysis were the business model categories outlined above. Relating to the first research question, we compared the business models of the two airlines across all categories and evaluated to what extent they still represent FSCs. This was done in the first part of the findings section. Relating to the second research question, we focused in the second part on the categories in which the management of the two airlines tried to move the business model closer to the LCC model against the resistance of employee representatives. We then evaluated to what extent employee representatives' resistance, and the underpinning institutional context, influenced the business model change. Proposition building in our discussion section has been guided by the observed relationship between institutional context and business model change.

\section{EMPIRICAL FINDINGS}

\section{Comparison of the Business Models of British Airways and Lufthansa in 2012/13}

Both BA and LH still represent FSCs. They lead international alliances and do not receive subsidies from airports (see Table 4). They have collective agreements that constrain policy choices: BA has a '100 passengers' scope clause, which means that flights with more than 100 passengers have to be manned by pilots on the BA seniority list, and LH has a '95 passengers' scope clause.

Both airlines have also realised that LCCs pose a serious threat to their established business model and have adopted some elements of the LCC business model. However, significant 
differences exist between the two airlines regarding the extent to which they have moved their business model towards that of LCCs.

BA has moved more than LH towards the LCC business model with respect to six categories. Salaries for both cabin crew and pilots have been significantly reduced and its average labour costs per employee are significantly below those of LH. Investment in the training and development of employees has also been reduced and recruitment standards for all cabin crew members have been lowered. BA reduced the variety of aircraft at an early stage and plans to go further in this direction. The leasing of aircraft has become more important and its importance appears to be further increasing. The collective agreement and the 100 passengers scope clause is still in existence; however, the union's attempt to extend the scope clause to BA's new subsidiary in France, OpenSkies, failed without having gained any concessions from management. Due to the fact that BA's labour costs are significantly below those of LH, the cost implications of this scope clause are less severe for BA than for LH.

Although $\mathrm{BA}$ is closer to the low cost model regarding variety of aircraft and collective arrangements, LH has recently reduced the variety of aircraft and modified the scope clause from '70 passengers' to '95 passengers'. In return, the management conceded to the demands of the pilot union regarding its foreign subsidiary airlines (see below).

Insert Table 4 about here 


\section{The Influence of Employee Representation on Business Model Changes}

\section{British Airways}

Since 2011, BA has been a branch of the UK-based International Airlines Group (IAG), together with the airlines Iberia and Vueling (Financial Times/FT, 2010; Guardian 2010a). Compared to LH, employee representation had only a limited influence on business model changes at BA.

A strong focus on reducing labour costs, reduced investment in training and development and lowering of recruitment standards: Our comparison in Table 4 displays six categories where BA has moved closer to the LCC model. The reduction in average labour costs and in investment in training and development is most conspicuous in comparison with LH. BA has reduced the recruiting standards for its cabin crew members. According to the British Airlines Stewards and Stewardesses Association (BASSA), management is now interested in a 'cheap crew' which can be replaced on a regular basis (TU/UK/1). BA has also terminated its financial support for pilot training. The airline has emulated the easyJet model, in which pilots can pay for their training by using a loan scheme that provides them with tax relief $(\mathrm{C} / \mathrm{UK} / 2 ; \mathrm{TU} / \mathrm{UK} / 3)$.

In the mid-1990s, BA was already eager to reduce costs to compete on short-haul flights. Average basic salaries, holiday entitlements, perks and allowances were significantly reduced for pilots and cabin crew. Since 2008, BA has attempted to directly compete with easyJet in terms of labour unit costs (TU/UK/4). During strike actions from 2008 to 2010, BA developed a new approach of dealing with industrial conflicts, which involved taking legal action (FT, 2009a). For example, BA took BASSA to court after a strike ballot was held in 2009 in a dispute over job cuts; this industrial action was finally blocked by a court injunction deeming the ballot illegal (FT, 
2009b). BA also took disciplinary action and terminated the employment of BASSA representatives who had had leading roles in the strike actions (Upchurch, 2010).

The biggest dispute of the last five years, the 22 days strike action of cabin crew in 2010 , costing the firm more than $£ 180$ million (Guardian, 2010b), was triggered by proposed labour cost reductions. These cuts focused on the 'dismantling of its seniority system of promotion, restructuring of cabin crew operations and plans to bring pay in line with competitors' (Wilton, 2010). The outcome of this bitter dispute was the breakdown of relations with BASSA (Guardian, 2010c; 2010d), which represents the cabin crew, is a member of the Trades Union Congress (TUC) and is a branch of Unite. ${ }^{5}$ In June 2011, the union and BA eventually reached an agreement: BA reported that it had reduced costs as a result of the changes, which led to savings of $£ 60$ million annually (Daily Telegraph, 2011). After this conflict, BASSA was only invited to obligatory health and safety meetings. However, after the then CEO, Willie Walsh, left BA and became the CEO of the new parent company IAG, relations between management and BASSA improved: his successor, Keith Williams, resumed official talks with BASSA in 2011 (FT, 2011a; 2011b).

The British Airline Pilots Association (BALPA), which is part of the TUC and represents the pilots of BA and also of easyJet, has also been put under pressure to cut costs over the years. In comparison to BASSA, BALPA was more willing to make concessions to avoid severe conflicts. An example of this approach is the recent implementation of new cost-saving measures. BALPA agreed to a programme saving $£ 10$ million, which runs from 2012 to 2015 , including reductions in annual leave from 30 to 28 days. In return, BA dropped its initial plans to develop British Midland Airways (BMI) into a new LCC of BA after its takeover from LH in 2012 (TU/UK/6).

Collective agreements and their influence on policy choices: We found some important collective agreements, such as the memorandum agreement between BA and BALPA, which 
contains mutual arrangements including salary, sick pay, loss of license protection and scope clauses. There is, for example, the '100 passengers' scope clause, that all flights out of Gatwick and Heathrow have to be manned by BA pilots listed on the mainline seniority list (TU/UK6). When BA launched the new upmarket subsidiary OpenSkies in France, BALPA sought to extend the '100 passengers' scope clause, but BA wanted to operate OpenSkies with a separate, cheaper pilot work force, which was not listed on the same seniority list as BA pilots (BBC News, 2008). $90 \%$ of BA pilots voted for strike action (Guardian, 2008). The strike was finally cancelled because of the court's decision that BA would be able to sue BALPA for 'unlimited damages'. BALPA calculated that strike action would cost them $£ 100$ million, a price the union was unable to pay (TU/UK/3). The BALPA representative summarises this new situation as follows:

'They've taken BALPA to court on a number of occasions. I'm sure they will continue to do so. So there is this threat coming through of using the courts more to try and beat us. So we are conscious that if we ever got into a dispute with BA, it would be really unpleasant' (ibid).

Foundation of LCCs and the continuous threat of setting up a new one: The airline realised in the mid-1990s that the new competition of LCCs threatened its business model. In 1998, BA launched the LCC Go, but sold it in 2001. Go was the brainchild of CEO Bob Ayling (1996-2000), but his successor Rod Eddington saw less strategic value in the LCC, because it did not fit with BA's new strategy of focusing more on long-haul flights and premium customers (Guardian, 2006; TU/UK/4) and it attracted customers away from its parent company (Harvey and Turnbull, 2010). However, we found some evidence that the takeover of BMI in 2012 was used to put pressure on the unions and gain concessions in the form of significant cost cuts. Renewed pressure on unions appeared when BA's and Iberia's parent company, IAG, won control over the Spanish LCC 
Vueling, and started to 'seek large cost savings by using Vueling to provide short-haul services currently done by its UK and Spanish airlines' (FT, 2013a; 2013b).

\section{Deutsche Lufthansa}

The Passenger Airlines Group of LH consists of the core airline LH (LH Classic), LH Regional (LH CityLine, Air Dolomiti and Eurowings), the LCC Germanwings and the foreign subsidiaries (SWISS and Austrian Airlines). Employee representatives have influenced business model change with respect to labour costs, investment in training and development, collective agreements, variety of aircraft models and the company-owned LCC.

Labour costs and investment in training and development: In 2010, the average labour costs per employee were US\$110.000 at LH Classic. The average labour costs at BA were US\$77.000, $30 \%$ below the labour costs at LH Classic (Frankfurter Allgemeine Zeitung/FAZ, 2011). ${ }^{6}$ Given the fact that labour costs account for $40 \%$ of LH Classic's fixed costs (fuel costs and fees account for $30 \%$ ), this difference is significant (FAZ, 2012a). There are indications that the aggregate labour costs of Germanwings (including pilots) are 25\% (FAZ, 2012b) below those of LH Classic. The labour costs for cabin crew are significantly below those of LH Classic (TU/GER/2). However, the aggregate labour costs of Germanwings seem to be slightly above those of BA, because they are only $25 \%$ and not $30 \%$ below those of LH Classic.

Union influence contributed to the high labour costs of LH. In 2012, LH reported an operating loss of $€ 45$ million in total (Lufthansa, 2012). The newly-appointed CEO, Christoph Franz, tried to aggressively reduce labour costs. However, management made limited progress in reducing labour costs. Negotiations between Unabhängige Flugbegleiter Organisation (UFO), representing cabin crew members, and management led to an industrial action. The plan to reduce cabin crew labour costs contained two controversial issues. First, the management planned to employ 230 
temporary employees as cabin crew members, based at the airport in Berlin; temporary employees would have earned 30\% less than LH Classic employees (FAZ, 2012c). LH could have reduced the investment in training and development significantly, because the training of these temporary employees would be financed by themselves or publicly subsidised (Aviation Power, 2013). Furthermore, temporary employees are not allowed to go on strike (FAZ, 2012d). The management considered expanding the use of this cost-cutting option beyond its base in Berlin (FAZ, 2012e). Second, the management planned to merge parts of LH Classic and LH Regional with Germanwings. This merger would have necessitated a new collective agreement, which would have reduced employee wages to the level of Germanwings. This could have affected 2,000 LH Classic cabin crew members, resulting in wage cuts of up to $40 \%$ (FAZ, 2012f, FAZ, 2012g). UFO opposed these plans and demanded a 5\% wage increase instead. UFO then went on strike (FAZ, 2012h). After an arbitration process, a compromise was reached. The management agreed to refrain from the employment of temporary employees in the future. LH Classic cabin crew members were not negatively affected by the merger; they could transfer to the 'new' Germanwings, but without any cuts in wages, or change over to one of the LH hubs. Wages were increased by $4.6 \%$. In return, UFO accepted lower wages for cabin crew members recruited in the future (FAZ, 2012i). Franz admitted publicly that he had underestimated the power of the union (FAZ, 2012j). This shows that, even in a difficult economic environment, LH's management is not able to significantly reduce labour costs because of union influence.

Collective agreements and variety of aircraft models: In 1992, LH was close to bankruptcy. The unions agreed on substantial pay cuts. In return, the management accepted a group collective bargaining agreement (Konzerntarifvertrag, henceforth called KTV). The KTV stipulated that flights with more than 70 passengers (the ' 70 rule') had to be operated by the core airline $\mathrm{LH}$; 
Changing Business Models

conversely, they were not allowed to be operated by its regional airlines, which are owned by LH but have separate collective agreements and lower cost structures. For LH CityLine, the consequence was that, to comply with the KTV, they had to primarily use aircraft with 50 seats or only use 70 seats of an 80 -seat aircraft, although they would have needed 140 seats on their shorthaul flights to fly profitably (FTD, 2003).

Following threats of strike action, in 2004, the pilot union Vereinigung Cockpit (henceforth called Cockpit) achieved the integration of pilots flying for LH's newly-founded LCC Germanwings into the KTV. Starting from 2005, LH acquired several foreign airlines. This eventually led to a serious conflict with Cockpit in 2010. The acquired foreign airlines had significantly lower cost structures and Cockpit was concerned that management would shift the unprofitable routes operated by LH Classic to these cheaper airlines (FAZ, 2010a). The pilot union called for integration of these airlines into the KTV, which would have substantially reduced their cost advantages. The management argued that the KTV was not applicable to foreign subsidiary airlines; eventually the management and Cockpit reached an agreement.

'It was profound knowledge of the material, combined with frank candidness, which helped the judge to soften the inflexible negotiating positions. "You both might be right", she said, (...) "but in the end you have to resume the talks, the sooner the better." (...) legal advisors and their clients smiled surprised. And then they asked themselves the question: why actually not? What was the purpose of Lufthansa filing a petition that the strike was totally or partially unlawful?' (FAZ, 2010b)

The '70 rule' was changed to a '95 rule', meaning that only flights with more than 95 passengers have to be operated by pilots integrated into the KTV. Flights with fewer passengers are allowed to be operated by LH Regional. This allows aircraft models with larger capacity to be 
purchased for LH Regional. The '95 rule' contains a dynamic component, allowing $20 \%$ of the entire LH air fleet, relating to the smallest aircraft, to be operated by LH Regional, even if they have more than 95 passenger seats $(\mathrm{C} / \mathrm{GER} / 3)$. When asked about concessions, an executive replied:

'The hardest thing for us was to discuss these strategic issues at all. The management does not want to discuss issues that constrain its strategic leeway in any way. A key objective of unions, however, is to constrain our leeway. From this perspective, the compromises are painful for us. But the compromises are viable. I would have preferred 150 seats instead of 70, but the compromise was 95 seats plus a dynamic component. This is not the result we aimed for, but it is still a good result.' (C/GER/3)

Cockpit succeeded in including the issue of cheaper foreign subsidiary airlines in negotiations, and establishing formal rules that preclude the management from transferring routes of LH Classic to those airlines $(\mathrm{C} / \mathrm{GER} / 3)$.

Foundation of an LCC: LH entered the LCC market in 2002 through Germanwings (Bamber et al., 2009). The founding of Germanwings and LH's role as a minority shareholder was a deliberate attempt to gain market share in this segment. Not only the wages but also the recruiting standards are significantly below those of LH Classic (TU/GER/1; TU/GER/2). A key motivation behind the foundation of Germanwings was to circumvent the constraints of the KTV (C/GER/3).

'Starting from the year 2000 the LCC field developed a dynamic of its own and this galvanized us. The question arose how to deal with this phenomenon as a company. The answer was the foundation of Germanwings, which we deliberately founded outside all these collective bargaining agreements.' (C/GER/3) 
Cockpit's concern was that the management would transfer unprofitable LH Classic routes to Germanwings. Cockpit called for an integration of Germanwings into the KTV and eventually achieved this goal in 2004. The salaries of pilots at Germanwings are still below those of LH Classic, but this cost advantage is largely offset by the fact that these pilots are promoted more quickly (TU/GER/1; C/GER/3). Germanwings became a wholly-owned subsidiary of LH in 2009 (Barry and Nienhüser, 2010).

The growth of Germanwings has been modest in comparison with that of easyJet. In 2010, its fleet contained 30 aircraft, whereas easyJet had 180 (Lufthansa, 2010). A strategy expert at LH emphasised this point:

'The profitability of Germanwings is negatively affected by the fact that their business model is not based on such growth as that of easyJet. (...) The low cost model has only been working when it is based on strong growth. The basic flaw of the Germanwings business model has been that it was and is embedded in a governance structure in which this growth is simply impossible. To have a LCC is possible for Lufthansa, but then you have to ensure that they (Germanwings) can make an order for 30 aircraft without needing the approval of the LH supervisory board. Because you have all these employee representatives sitting there (on the board) and they are concerned about the implications for their own jobs.' (C/GER/5)

The pilots' representatives are wary of aggressive growth plans for Germanwings, because the promotion to captain at LH Classic towards which most LH pilots work is linked to the growth of LH Classic and not to that of Germanwings (C/GER/6).

In addition, UFO influenced the development of Germanwings. In contrast to initial plans proposed by the management, cabin crew members of LH Classic were not negatively affected by 
the merger of parts of their airline with Germanwings. Instead, they were offered the option to change to Germanwings without any wage reductions, which made it more difficult for Germanwings to achieve the cost structures of LCCs.

\section{Additional Factors Affecting Business Model Change at British Airways and Lufthansa}

Another differentiating factor was the exposure to competition. BA was the first airline that was exposed to competition from LCCs (Wirtschaftswoche, 2011; C/GER/5). This could explain why BA has adopted more elements of the LCC model. However, the competition that LH faces from LCCs and Gulf airlines has increased recently. Gulf airlines have substantially reduced LH's profit margins on intercontinental routes (FAZ, 2012k). LH is more focused on Asia than BA and therefore even more affected by these airlines (TU/UK/6). There are also indications that the competition LH is facing from Ryanair and easyJet is likely to increase (FAZ, 2012k). However, despite the recently increased competition for $\mathrm{LH}$, the ambitious plans to cut labour costs substantially fell short of expectations, because of union resistance. Hence, employee representation has significantly influenced business model change at LH. Furthermore, the level of home market competition and institutions providing rights to employee representatives are interrelated. In 2003, easyJet considered an acquisition of Deutsche BA in order to grow in Germany, but eventually decided against it. According to a former easyJet executive, this was because of unions, which made cost reductions very difficult (C/UK/4).

\section{DISCUSSION AND CONCLUSION}

The first research question of this paper aims to discern the extent to which the FSCs BA and LH have changed their business model in reaction to the low cost pressure exerted by LCCs. Both 
BA and LH still represent FSCs. But, to some extent, both airlines have also moved their business model in the direction of LCCs. The analysis revealed that, in the majority of business model categories, BA moved closer to the LCC model. This shows that established companies are (at least to some extent) able to overcome the barriers discussed in the literature and institutional barriers. This leads us to the question of whether employee representation, and the fact that institutions provide more wide-ranging rights to employee representatives in Germany than in the UK, has influenced how the two FSCs changed their business model in response to pressure from LCCs.

At BA, the influence of BASSA on business model change was minimal, and that of BALPA quite limited. When BASSA started organising industrial action in 2009 to prevent job cuts, the industrial action was blocked by a court injunction. When BALPA organised industrial action to achieve the extension of the scope clause to OpenSkies, the strike was eventually cancelled because of the court's decision that BA could sue the union. In 2012, BALPA was able to prevent management from developing the newly-acquired BMI into an LCC, but only by making substantial concessions to management.

At $\mathrm{LH}$, in comparison with BA, employee representatives had a more significant influence on business model change. In 2004, Cockpit achieved the integration of Germanwings into the KTV at the level of pilots. Pilot representatives on its supervisory board used their position to work against the ambitious growth of Germanwings. In 2010, rules were established that precluded the management from transferring routes to cheaper foreign airlines, because the German court refused to declare potential strike action by Cockpit illegal. Unions made substantial reductions in labour costs quite difficult. UFO went on strike in 2012 and prevented the management from employing temporary employees and from transferring LH Classic cabin crew members to Germanwings for 
lower wages. The level of competition may also have been a reason for the more limited shift of LH towards the LCC business model. However, despite the fact that the level of competition LH is facing has recently increased considerably, the plans to cut labour costs fell substantially short of expectations because of the resistance of employee representatives.

Our study fills an important research gap in research on business models identified by Zott and Amit (2013), namely how the environments in which firms are embedded shape their business models. We make a theoretical contribution by showing that national institutions, in the form of employee representative regimes, can significantly shape business models and changes therein. This particularly applies to market economies such as Germany, in which institutions provide executives with employee representatives with wider-ranging rights than institutions in more liberal market economies such as the UK (Crossland and Hambrick, 2011; Hall and Soskice, 2001). Employee representatives were able to influence the change of LH's business model because their position is strengthened by the institutional framework. The use of industrial action as a mechanism to force management to mitigate business model changes was increasingly threatened in the UK by court decisions in favour of BA management, in sharp contrast to Germany. These results are notable because the airline industry is global and competitive, and FSCs are therefore under considerable pressure from two sides, from LCCs but also from newly established FSCs such as the Gulf airlines. This means that, even in a difficult and fiercely competitive market environment, the employee representation regime of Germany affected business model change at LH significantly. Hence, we propose the following:

The extent to which business models can be changed against the interests of the employees is significantly more limited in countries in which the institutional framework provides wide-ranging 
Changing Business Models

rights to employee representatives than it is in countries in which only limited rights are provided. This even applies to industries that are fiercely competitive and global in nature.

Apart from the fact that LH was more constrained than BA in changing its business model, there were also some similarities in the way that both companies used LCCs or airlines with lower cost structures, which they had acquired or founded, as a tool to put pressure on and gain concessions from unions. LH ventured into the LCC segment via Germanwings. This LCC was founded outside collective agreements to reduce costs and to put pressure on employee representatives. Management did not achieve all their goals. Germanwings was integrated into the KTV at the level of pilots, which increased costs. However, the management created an LCC that was, at least to some extent, able to compete with other LCCs and that could be used as a bargaining chip in negotiations. Foreign subsidiary airlines with a cheaper workforce, fulfilled at a later stage a similar 'bargaining chip' function. This is the main reason why LH, despite facing significant barriers, could move its business model at least to some extent towards that of LCCs. BA entered the LCC segment with its launch of Go in 1998, but withdrew from it in 2001. BA re-entered the LCC segment with the LCC Vueling, which is owned by its parent company IAG, and used Vueling and BMI, which they had acquired in 2012, to put pressures on unions. Hence, both BA and LH employed this approach to gain concessions from employee representatives. However, our comparisons also show that LH employed this approach earlier, continuously and more extensively. This is possibly due to the fact that LH faced more institutional constraints which mitigated significant changes of its business model, when compared to the changes we observed at BA. This is also in line with recent work in strategic management (Peteraf and Reed, 2007) which shows that, even in a highly constraining institutional environment, managers are able to exercise some strategic choice. We add to this literature by identifying a mechanism which enables 
firms to exercise strategic choice: the acquisition or foundation of companies outside these constraints.

The main contribution of this study is that national institutions that potentially strengthen the position of employee representatives are identified as a factor that can influence, and act as a barrier to, business model change. This factor can have an influence on the extent of the business model change, as well as on the approach of business model change. This means that business model scholars have to take into account the institutional environment in which firms are embedded when analysing attempts to change business models. This perspective is missing in the emerging field of business model research. Related to this, business model scholars should also investigate how firms seeking to change their business model when facing institutional constraints, and in doing so try to overcome these barriers.

The business model concept is still relatively new in the strategic management field. In this study, we followed Zott and Amit (2008) in their distinction of product market strategies, i.e. how a firm positions itself against competitors, from business models, i.e. how it transacts with exchange partners. We deem this distinction as useful, because it is possible that companies pursue similar strategies with quite different business models. In fact, despite some significant differences in their business models, the product market strategies of BA and LH are quite similar in several ways (e.g. in terms of price of fares, focus on business customers, long-haul flights, and high service quality). This finding is also interesting from a theoretical point of view, because it shows that the strategy/business models distinction facilitates a more fine-grained comparison of core activities between firms. Thereby, our approach enriches the field of strategic management.

Our study has limitations. The analysis is confined to two companies; a comparison of more FSCs would have made the results more robust for generalisation. The study could also have been 
based on more than 23 interviews with experts, but the fact that we were able to conduct interviews with actors directly involved in the negotiations strengthened the study's internal validity. Finally, it is conceivable that factors other than the influence of employee representation affect the outcomes of business model change, but these factors are beyond the scope of this paper.

The fact that this study only analysed the effect of institutions which potentially strengthen the position of employee representatives opens up opportunities for future research. Whether other national institutions concerning human resource management hinder or favour business model changes in established companies could be investigated in future studies. Institutions regulating minimum wages, temporary work employment or contract flexibility might influence attempts of firms to change their business model. Another avenue of future study would be not only to analyse the effect of institutions on the change of business models, as carried out in this study, but also the impact of institutions on the emergence of business models. Finally, this study focused on power relations between management and unions. Future studies of business model changes could build on current debates by comparative institutionalists (Edwards and Bélanger, 2009; Geppert and Williams, 2006) and analyse the influence of the often contradictory interests and identities of different kinds of actors involved in actual processes of business model change. 


\section{REFERENCES}

Airscoop (2011). 'Ryanair's business model 2011. A peek into the airline's recipe for success'.

[Online], Available at: http://www.air-scoop.com/pdf/Ryanair-business-model_AirScoop_2011.pdf [Accessed on 22 June 2013].

Alamdari, F. and S. Fagan (2005). 'Impact of the adherence to the original low-cost model on the profitability of low-cost airlines', Transport Reviews, 25, pp. 377-392.

Albert, M. (1993). Capitalism against Capitalism. London: Whurr.

Amit, R. and C. Zott (2001). 'Value creation in e-business', Strategic Management Journal, 22, pp. $493-520$.

Aviation Power (2013). 'Aviation Power Academy'. [Online], Available at: http://www.aviationpower.de/ap-academy.html [Accessed on 13 June 2013].

Baden-Fuller, C., B. Demil, X. Lecoq and I. MacMillan (2010). 'Editorial', Long Range Planning, 43, pp. 143-145.

Bamber, G. J., J. H. Gittell, T. A. Kochan and A. von Nordenflycht (2009). 'Contrasting management and employment-relations strategies in European airlines', Journal of Industrial Relations, 51, pp. 635-652.

Barry, M. and W. Nienhüser (2010). 'Coordinated market economy/liberal employment relations: low cost competition in the German aviation industry'. International Journal of Human Resource Management, 21, pp. 214-229.

Bazargan, M., A. Vijayanarayanan, H. Kosalim and T. Simms (2011). 'Aircraft Replacement Strategy'. London: AGIFORS Airlines Operations Conference, 19 May. Available at: http://www.agifors.org/studygrp/opsct1/2011/ [Accessed on 09 May 2013]. 
BBC News (2008). 'BA seeks resolution in pilot row'. 21 February. Available at: http://news.bbc.co.uk/1/hi/business/7256487.stm [Accessed on 12 April 2014].

Bowman, E. H. (1978). 'Strategy, annual reports and alchemy', California Management Review, 20, pp. 64-71.

British Airways (2010). 'Annual Report'. Available at: http://www.iairgroup.com/phoenix.zhtml?c=240949\&p=irol-reportsannual [Accessed on 09 May 2013].

British Airways (2011). 'Annual Report'. Available at: http://www.iairgroup.com/phoenix.zhtml?c=240949\&p=irol-reportsannual [Accessed on 09 May 2013].

British Airways (2012). 'Annual Report'. Available at: http://www.iairgroup.com/phoenix.zhtml?c=240949\&p=irol-reportsannual [Accessed on 09 May 2013].

Casadesus-Masanell, R. and J. E. Ricart (2010). 'From strategy to business models and onto tactics', Long Range Planning, 43, pp. 195-215.

Chesbrough, H. and R. S. Rosenbloom (2002). 'The role of the business model in capturing value from innovation: evidence from Xerox corporation's technology spin-off companies', Industrial and Corporate Change, 11, pp. 529-555.

Crossland, C. and D. C. Hambrick (2007). 'How national systems differ in their constraints on corporate executives: a study of CEO effects in three countries', Strategic Management Journal, 28, pp. 767-789. 
Crossland, C. and D. C. Hambrick (2011). 'Differences in managerial discretion across countries: how nation-level institutions affect the degree to which CEOs matter', Strategic Management Journal, 32, pp. 797-819.

Daily Telegraph (2011). 'British Airways dispute finally over', 22 June.

Decker, C. and K. Lange (2013). 'Exploring a secretive organization: what can we learn about family offices from the public sphere?', Organizational Dynamics, 4, pp. 298-306.

Delfmann, W., H. Baum, S. Auerbach and S. Albers (eds) (2005). Strategic Management in the Aviation Industry. Aldershot: Ashgate.

Edwards, P. and J. Bélanger (2009). ‘The multinational firm as a contested terrain'. In S. Collinson and G. Morgan (eds), Images of the Multinational Firm, pp. 193-216. Chichester: Wiley \& Sons.

Eisenhardt, K. M. (1989). 'Building theories from case study research', Academy of Management Journal, 14, pp. 532-550.

Financial Times (2009a). 'BA’s legal fight against strike draws a crowd', 16 December, p. 14.

Financial Times (2009b). 'Reprieve for BA passengers as court rules strike action invalid', 17 December, p. 18.

Financial Times (2010). 'BA and Iberia on course for merger', 8 April, p. 19.

Financial Times (2011a). 'United backs deal to end BA cabin crew dispute', 12 May, p. 3.

Financial Times (2011b). 'BA cabin crew in landslide vote for peace deal'. 22 June, p. 2.

Financial Times (2013a). 'IAG’s Vueling plan risks union conflict', 27 January.

Financial Times (2013b). 'IAG poised to gain control of Vueling', 23 April.

Financial Times Deutschland (2003). 'Zu viel Ballast an Bord', 4 June, p. 25. 
Fiss, P. C. and E. J. Zajac (2004). 'The diffusion of ideas over contested terrain: the (non) adoption of a shareholder value orientation among German firms', Administrative Science Quarterly, 49, pp. 501-534.

Frankfurter Allgemeine Zeitung. (2008). 'Unternehmensnachrichten', 9 December, p. 20.

Frankfurter Allgemeine Zeitung. (2010a). 'Lufthansa-Piloten streiken womöglich doch'. 23 March, p. 35.

Frankfurter Allgemeine Zeitung (2010b). 'Reden müssen sie doch wieder miteinander', 24 February, p. 39.

Frankfurter Allgemeine Zeitung (2011). 'Emirates profitiert von niedrigen Löhnen', 7 July, p. 14. Frankfurter Allgemeine Zeitung (2012a). 'Der riskante Kurs der Lufthansa', 5 May, p. 19.

Frankfurter Allgemeine Zeitung (2012b). 'Lufthansa will Billig-Fluggesellschaft gründen', 28 April, p. 11.

Frankfurter Allgemeine Zeitung (2012c). 'Flugbegleiter kündigen Streik im ganzen Land an', 5 September, p. 11 .

Frankfurter Allgemeine Zeitung (2012d). 'Lufthansa und Flugbegleiter vereinbaren Schlichtung', 7 September, FAZ.NET.

Frankfurter Allgemeine Zeitung (2012e). 'Lufthana darf Leih-Stewardessen rekrutieren', 15 February, FAZ.NET.

Frankfurter Allgemeine Zeitung (2012f). 'Lufthansa-Gesamtpaket gescheitert', 17 August, FAZ.NET.

Frankfurter Allgemeine Zeitung (2012g). 'Widerstände gegen Lufthansa-Sparpläne', 7 August, p. 13. 
Frankfurter Allgemeine Zeitung (2012h). 'Grösster Ausstand in der Konzerngeschichte: Stillstand bei der Lufthansa', 8 September, p. 17.

Frankfurter Allgemeine Zeitung (2012i). 'Tarifkonflikt bei Lufthansa beigelegt', 14 November, p. 9.

Frankfurter Allgemeine Zeitung (2012j). 'Lufthansa streicht die Hälfte aller Fluege', 6 September, FAZ.NET.

Frankfurter Allgemeine Zeitung (2012k). 'Billig will gekonnt sein', 30 September, FAZ.NET.

Frankfurter Allgemeine Zeitung (20121). 'Die Politik missbraucht uns als Goldesel', 17 November, FAZ.NET.

Froud, J., S. Johal, A. Leaver, R. Phillips and K. Williams (2009). 'Stressed by choice: A business model analysis of the BBC', British Journal of Management, 20, pp. 252-264.

Geppert, M. and K. Williams (2006). 'Global, national and local practices in multinational corporations: towards a sociopolitical framework', International Journal of Human Resource Management, 17, pp. 49-69.

Guardian (2006). 'BA slashes fares to take on low-cost airlines', 20 April.

Guardian (2008). 'British Airways pilots vote to strike', 21 February.

Guardian (2010a). 'British Airways and Iberia: How the merger partners stack up, 8 April.

Guardian (2010b). 'British Airways cabin crew reject pay offer', 20 July.

Guardian (2010c). 'British Airways dispute will undermine staff relations for years', 30 March.

Guardian (2010d). 'Unite sacking is another British Airways own goal', 7 May.

Hales-Dutton, B. (2003). 'The rise of Ryanair', Aircraft Illustrated, pp. 28-33. 
Hall, P. and D. Soskice (2001). 'An introduction to varieties of capitalism'. In P. Hall and D. Soskice (eds), Varieties of Capitalism: The Institutional Foundations of Comparative Advantage, pp. 1-68. Oxford: Oxford University Press.

Hambrick, D. C. and S. Finkelstein (1987). 'Managerial discretion: a bridge between polar views on organizations'. In L. L. Cummings and M. Staw (eds), Research in Organizational Behavior, pp. 369-406. Greenwich, CT: JAI Press.

Harvey, G. and P. Turnbull (2010). 'On the Go: walking the high road at a low cost airline', International Journal of Human Resource Management, 21, pp. 230-241.

Hellgren, B., J. Loewstedt, L. Puttonen, J. Tienari, E. Vaara and A. Werr (2002). 'How issues become (re)constructed in the media: discursive practices in the AstraZeneca merger', British Journal of Management, 13, pp. 123-140.

Hooghiemstra, R. (2008). 'East-West attributions for company performance: a content analysis of Japanese and U.S. corporate annual reports', Journal of Cross-Cultural Psychology, 39, pp. 618-629.

Hunter, L. (2006). 'Low cost airlines: business model and employment relations', Management Focus and Employment Relations, 24, pp. 315-321.

Jick, T. D. (1979). 'Mixing qualitative and quantitative methods: triangulation in action', Administrative Science Quarterly, 24, pp. 602-611.

Langley, A. (1999). 'Strategies for theorizing from process data', Academy of Management Review, 24, pp. 691-710.

Lufthansa (2010) 'Annual Report'. Available at: http://investorrelations.lufthansagroup.com/fileadmin/downloads/en/financial-reports/annual-reports/LHAR-2010-e.pdf [Accessed on 23 May 2012]. 
Changing Business Models

Lufthansa (2011) 'Annual Report'. Available at: $\underline{\text { http://investor- }}$ relations.lufthansagroup.com/fileadmin/downloads/en/financial-reports/annual-reports/LHAR-2011-e.pdf [Accessed on 09 May 2013].

Lufthansa (2012) 'Annual Report'. Available at: $\underline{\text { http://investor- }}$ relations.lufthansagroup.com/fileadmin/downloads/en/financial-reports/annual-reports/LHAR-2012-e.pdf [Accessed on 09 May 2013].

Malighetti, P., S. Paleari and R. Redondi (2009). 'Pricing strategies of low-cost airlines: the Ryanair case study', Journal of Air Transport Management, 15, pp. 195-203.

Miozzo, M., M. Lehrer, R. DeFillippi, D. Grimshaw and A. Ordanini (2012). 'Economies of scope through multi-unit skill systems', British Journal of Management, 23, pp. 145-164.

Patzelt, H., D. Zu Knyphausen-Aufsess and P. Nikol (2008). 'Top management teams, business models and performance of biotechnology ventures: an upper echelon perspective', British Journal of Management, 19, pp. 205-221.

Peteraf, M. and R. Reed (2007). 'Managerial discretion and internal alignment under regulatory constraints and change', Strategic Management Journal, 28, pp. 1089-1112.

Peteraf, M. and R. Reed (2008). 'Regulatory reform and managerial choice: an analysis of the cost savings from airline deregulation', Managerial and Decision Economics, 29, pp. 99-116.

Porter, M. E. (1996). 'What is strategy?', Harvard Business Review, 74, pp. 61-78.

Schneider, M. and M. Paunescu (2012). 'Changing varieties of capitalism and revealed comparative advantages from 1990 top 2005: a test of the Hall and Soskice claims', SocioEconomic Review, 10, pp. 731-753.

Siegel, J. I. and B. Z. Larson (2009). 'Labor market institutions and global strategic adaptation: evidence from Lincoln Electric', Management Science, 55, pp. 1527-1546. 
Streeck, W. (1997). 'Beneficial constraints: on the economic limits of rational voluntarism'. In R. Hollingsworth and R. Boyer (eds), Contemporary Capitalism: The Embeddedness of Institutions, pp. 33-54. Cambridge: Cambridge University Press.

Upchurch, M. (2010). 'Creating a sustainable work environment in British Airways: implications of the 2010 cabin crew dispute', Technical Report, Middlesex University, London.

Wilton, N. (2010). An Introduction to HRM: Case Study Thirteen: the anatomy of a strike - British Airways and Unite. London: Sage.

Wirtschaftswoche (2011). 'Zurück in die Zukunft', 11 April, p. 50.

Whitley, R. (1999). Divergent Capitalisms: The Social Structuring and Change of Business Systems. Oxford: Oxford University Press.

Zott, C. and R. Amit (2007). 'Business model design and the performance of entrepreneurial firms', Organization Science, 18, pp. 181-199.

Zott, C. and R. Amit (2008). 'The fit between product market strategy and business model: implications for firm performance', Strategic Management Journal, 29, pp. 1-26.

Zott, C., R. Amit and L. Massa (2011). 'The business model: recent developments and future research', Journal of Management, 37, pp. 1019-1042.

Zott, C. and R. Amit (2013). 'The business model: a theoretically anchored robust construct for strategic analysis', Strategic Organization, 11, pp. 403-411. 


\section{FOOTNOTES}

${ }^{1}$ Casadesus-Masanell and Ricart (2010) include in their analysis of Ryanair's business model also choices related to the positioning of the firm against its competitors (e.g., served customer segment, geographic market and the firm's product offerings). In the current study, we adhere to Amit and Zott's distinction of business model and product market strategy, and consequently exclude such choices from our empirical analysis (p. 4).

${ }^{2}$ It is worth mentioning here, that we distinguish between trade unions, seen as exchange partners (business model), and institutions. The latter potentially strengthen employee representatives such as trade unions. We do this for two reasons. First, airlines operating in institutional environments which are not supportive of trade unions may nevertheless decide to transact with unions and treat them as important exchange partners. The US-based Southwest Airlines low-cost carrier is a case in point. Its management pursues a partnership-approach with unions, although there is no institutional pressure to do so. Second, our empirical evidence shows that airlines operating in institutional environments supportive of trade unions are by no means passive actors. This was highlighted by one of our interview partners: “They (the cabin crew trade union UFO) signed the first collective agreement with LTU and then with Lufthansa. At that time, it was the official policy of Lufthansa to strengthen occupational trade unions (at the expense of industry unions such as ver.di). This also included the cockpit union (TU/GER/1)." According to the interview, the LH management preferred occupational over industry unions back then due to the fact that the representatives of the former unions possessed superior industry knowledge. This quote clearly demonstrates that even in such an institutional environment companies have some discretion when dealing with unions as their exchange partners. Therefore, it makes sense to 
separate trade unions as exchange and business model partners from the wider institutional environment (p. 9).

${ }^{3}$ We analysed the Financial Times, the Guardian, the Economist, Business Week, Manager Magazine, the Wall Street Journal, the International Herald Tribune, Financial Times Deutschland, TAZ (die tageszeitung), Handelsblatt, Tagesspiegel, Börsenzeitung, Finanz und Wirtschaft, Frankfurter Allgemeine Zeitung, die Zeit, Neue Zürcher Zeitung, die Mitbestimmung, Süddeutsche Zeitung, Spiegel and Wochenpost, and BBC News for the period 2005-2010 (p. 10).

${ }^{4}$ Here we focus on current business model changes and not on how the business models have changed since 1993, the start year of our document analysis. Nevertheless, our section indicates and reflects on typical patterns of former business model changes of both airlines, which we cannot illustrate in full length, given the space restrictions of journal articles (p. 11).

${ }^{5}$ The other important union at BA is GMB, which competes with Unite for terminal employees (p. 15).

${ }^{6}$ The figures in the newspaper article of the Frankfurter Allgemeine Zeitung (FAZ, 2011) are based on a study of Oxford Economics (p. 17). 
TABLES

TABLE 1: List of abbreviations used in the manuscript

\begin{tabular}{|l|l|}
\hline Low cost carrier & LCC \\
\hline Full service carrier & FSC \\
\hline British Airways & BA \\
\hline Deutsche Lufthansa & LH \\
\hline International Airlines Group & IAG \\
\hline British Midland Airways & BMI \\
\hline $\begin{array}{l}\text { British Airlines Stewards and Stewardesses } \\
\text { Association }\end{array}$ & BASSA \\
\hline British Airline Pilots Association & BALPA \\
\hline Trades Union Congress & TUC \\
\hline $\begin{array}{l}\text { Unabhängige Flugbegleiter Organisation } \\
\text { (Independent Flight Attendant Organization) }\end{array}$ & UFO \\
\hline Vereinigung Cockpit & Cockpit \\
\hline $\begin{array}{l}\text { Vereinte Dienstleistungsgewerkschaft } \\
\text { (United Services Trade Union) }\end{array}$ & ver.di \\
\hline $\begin{array}{l}\text { Konzerntarifvertrag (group collective } \\
\text { bargaining agreement) }\end{array}$ & KTV \\
\hline $\begin{array}{l}\text { Hamburgisches Welt-Wirtschafts-Archiv } \\
\text { (Hamburg World Economy Archive) }\end{array}$ & HWWA \\
\hline United Kingdom & UK \\
\hline Germany & GER \\
\hline Financial Times & FT \\
\hline Frankfurter Allgemeine Zeitung & FAZ \\
\hline
\end{tabular}


Changing Business Models

TABLE 2: List of conducted interviews

\begin{tabular}{|c|c|c|c|c|c|c|c|}
\hline $\begin{array}{l}\text { Type of } \\
\text { organisation }\end{array}$ & Country & Position & Organisation & Date & $\begin{array}{l}\text { Length and } \\
\text { type of } \\
\text { interview }\end{array}$ & $\begin{array}{l}\text { Involvement/ } \\
\text { area of } \\
\text { expertise }\end{array}$ & Code \\
\hline Trade Union & UK & Rep & BASSA & $24 / 01 / 2011$ & $\begin{array}{l}\text { Email; } \\
\text { response to } \\
\text { our requests }\end{array}$ & $\begin{array}{l}\text { General } \\
\text { BASSA Rep, } \\
\text { Main Office }\end{array}$ & TU/UK/1 \\
\hline Trade Union & UK & Rep & BASSA & $01 / 02 / 2011$ & $\begin{array}{l}35 \text { min; } \\
\text { telephone } \\
\text { interview }\end{array}$ & $\begin{array}{l}\text { General } \\
\text { BASSA Rep, } \\
\text { responsible for } \\
\text { health and } \\
\text { safety }\end{array}$ & TU/UK/2 \\
\hline Trade Union & UK & Rep & BALPA & $15 / 02 / 2011$ & $\begin{array}{l}100 \mathrm{~min} ; \\
\text { face-to-face } \\
\text { interview }\end{array}$ & $\begin{array}{l}\text { Principal } \\
\text { negotiator for } \\
\text { British } \\
\text { Airways }\end{array}$ & TU/UK/3 \\
\hline
\end{tabular}


Changing Business Models

\begin{tabular}{|c|c|c|c|c|c|c|c|}
\hline Trade Union & UK & Rep & BALPA & 29/03/2011 & $\begin{array}{l}50 \mathrm{~min} \text {; } \\
\text { face-to-face } \\
\text { interview }\end{array}$ & $\begin{array}{l}\text { Principal } \\
\text { negotiator for } \\
\text { easyJet }\end{array}$ & TU/UK/4 \\
\hline Trade Union & UK & Rep & BALPA & $14 / 05 / 2012$ & $\begin{array}{l}40 \text { min; } \\
\text { telephone } \\
\text { interview }\end{array}$ & $\begin{array}{l}\text { Principal } \\
\text { negotiator for } \\
\text { British } \\
\text { Airways }\end{array}$ & TU/UK/5 \\
\hline Trade union & UK & Rep & BALPA & $17 / 05 / 2013$ & $\begin{array}{l}40 \text { min; } \\
\text { telephone } \\
\text { interview }\end{array}$ & $\begin{array}{l}\text { Principal } \\
\text { negotiator for } \\
\text { British } \\
\text { Airways }\end{array}$ & TU/UK/6 \\
\hline Company/airline & UK & Executive & British Airways & 07/03/2011 & $\begin{array}{l}80 \mathrm{~min} ; \\
\text { face-to-face } \\
\text { interview }\end{array}$ & $\begin{array}{l}\text { Head of } \\
\text { Resourcing, } \\
\text { Industrial } \\
\text { Relations and } \\
\text { Strategy at } \\
\text { British } \\
\text { Airways }\end{array}$ & $\mathrm{C} / \mathrm{UK} / 1$ \\
\hline
\end{tabular}


Changing Business Models

\begin{tabular}{|c|c|c|c|c|c|c|c|}
\hline Company/airline & UK & Executive & British Airways & 08/08/2011 & $\begin{array}{l}62 \mathrm{~min} ; \\
\text { face-to-face } \\
\text { interview }\end{array}$ & $\begin{array}{l}\text { Head of } \\
\text { Resourcing, } \\
\text { Industrial } \\
\text { Relations and } \\
\text { Strategy at } \\
\text { British } \\
\text { Airways }\end{array}$ & $\mathrm{C} / \mathrm{UK} / 2$ \\
\hline Company/airline & UK & $\begin{array}{l}\text { Non- } \\
\text { executive } \\
\text { director }\end{array}$ & easyJet & $27 / 02 / 2013$ & $\begin{array}{l}10 \mathrm{~min} ; \\
\text { telephone } \\
\text { interview }\end{array}$ & $\begin{array}{l}\text { Expertise about } \\
\text { FSC and LCC } \\
\text { business } \\
\text { models }\end{array}$ & $\mathrm{C} / \mathrm{UK} / 3$ \\
\hline $\begin{array}{l}\text { Company/ } \\
\text { consultancy }\end{array}$ & UK & Consultant & March Friday & $28 / 02 / 2013$ & $\begin{array}{l}20 \mathrm{~min} ; \\
\text { telephone } \\
\text { interview }\end{array}$ & $\begin{array}{l}\text { Worked } \\
\text { previously as } \\
\text { Human } \\
\text { Resource } \\
\text { Executive at } \\
\text { easyJet }\end{array}$ & $\mathrm{C} / \mathrm{UK} / 4$ \\
\hline
\end{tabular}


Changing Business Models

\begin{tabular}{|c|c|c|c|c|c|c|c|}
\hline Company/airline & UK & Manager & British Airways & $17 / 05 / 2013$ & $\begin{array}{l}15 \text { min; } \\
\text { telephone } \\
\text { interview }\end{array}$ & $\begin{array}{l}\text { Expert on } \\
\text { emissions } \\
\text { trading }\end{array}$ & $\mathrm{C} / \mathrm{UK} / 5$ \\
\hline Company/airline & UK & Manager & British Airways & $11 / 06 / 2013$ & $\begin{array}{l}\text { Email; } \\
\text { response to } \\
\text { our requests }\end{array}$ & Media relations & $\mathrm{C} / \mathrm{UK} / 6$ \\
\hline Trade Union & $\begin{array}{l}\text { GER } \\
\text { (Germany) }\end{array}$ & Executive & UFO & $15 / 06 / 2010$ & $\begin{array}{l}50 \mathrm{~min} ; \\
\text { face-to-face } \\
\text { interview }\end{array}$ & $\begin{array}{l}\text { Directly } \\
\text { involved in } \\
\text { negotiations } \\
\text { with Lufthansa } \\
\text { management }\end{array}$ & TU/GER/1 \\
\hline
\end{tabular}


Changing Business Models

\begin{tabular}{|c|c|c|c|c|c|c|c|}
\hline Trade Union & GER & Executive & $\begin{array}{l}\text { ver.di (Vereinte } \\
\text { Dienstleistungsgewerkschaft) }\end{array}$ & $22 / 07 / 2010$ & $\begin{array}{l}120 \mathrm{~min} ; \\
\text { face-to-face } \\
\text { interview }\end{array}$ & $\begin{array}{l}\text { Directly } \\
\text { involved in } \\
\text { negotiations } \\
\text { with Lufthansa } \\
\text { management }\end{array}$ & TU/GER/2 \\
\hline Company/airline & GER & Executive & Airberlin & $02 / 02 / 2011$ & $\begin{array}{l}20 \text { min; } \\
\text { telephone } \\
\text { interview }\end{array}$ & $\begin{array}{l}\text { Head of Flight } \\
\text { Operation, } \\
\text { former head of } \\
\text { pilot training }\end{array}$ & C/GER/1 \\
\hline
\end{tabular}


Changing Business Models

\begin{tabular}{|c|c|c|c|c|c|c|c|}
\hline Company/airline & GER & $\begin{array}{l}\text { Human } \\
\text { Resource } \\
\text { Executive }\end{array}$ & Airberlin & 09/05/2011 & $\begin{array}{l}120 \mathrm{~min} \text {; } \\
\text { face-to-face } \\
\text { interview }\end{array}$ & $\begin{array}{l}\text { Directly } \\
\text { involved in } \\
\text { negotiations } \\
\text { with union } \\
\text { (ver.di), } \\
\text { worked } \\
\text { previously in } \\
\text { Human } \\
\text { Resources } \\
\text { department of } \\
\text { Lufthansa }\end{array}$ & $\mathrm{C} / \mathrm{GER} / 2$ \\
\hline Company/airline & GER & $\begin{array}{l}\text { Executive } \\
\text { Industrial } \\
\text { Relations }\end{array}$ & Deutsche Lufthansa & $10 / 05 / 2011$ & $\begin{array}{l}75 \mathrm{~min} \text {; } \\
\text { face-to-face } \\
\text { interview }\end{array}$ & $\begin{array}{l}\text { Directly } \\
\text { involved in } \\
\text { negotiations } \\
\text { with unions } \\
\text { (ver.di, UFO, } \\
\text { Cockpit) }\end{array}$ & $\mathrm{C} / \mathrm{GER} / 3$ \\
\hline
\end{tabular}


Changing Business Models

\begin{tabular}{|l|l|l|l|l|l|l|l|}
\hline Company/airline & GER & Executive & Airberlin & $31 / 05 / 2011$ & $\begin{array}{l}120 \text { min; } \\
\text { face-to-face } \\
\text { interview }\end{array}$ & $\begin{array}{l}\text { General } \\
\text { manager, } \\
\text { schedules } \\
\text { planning }\end{array}$ \\
\hline Company/airline & GER & $\begin{array}{l}\text { Senior } \\
\text { Manager }\end{array}$ & Deutsche Lufthansa & $15 / 07 / 2011$ & $\begin{array}{l}\text { C0 min; } \\
\text { face-to-face } \\
\text { interview }\end{array}$ & $\begin{array}{l}\text { Involved in } \\
\text { strategic } \\
\text { planning, } \\
\text { particularly } \\
\text { regarding } \\
\text { LCCs }\end{array}$ & $\begin{array}{l}\text { C/GER/5 } \\
\text { Company/airline }\end{array}$ \\
& GER & $\begin{array}{l}\text { Senior } \\
\text { Manager }\end{array}$ & Deutsche Lufthansa & $24 / 11 / 2011$ & $\begin{array}{l}55 \text { min; } \\
\text { telephone } \\
\text { interview }\end{array}$ & $\begin{array}{l}\text { Responsible for } \\
\text { pilot training of } \\
\text { Lufthansa } \\
\text { pilots }\end{array}$ \\
\hline
\end{tabular}


Changing Business Models

\begin{tabular}{|c|c|c|c|c|c|c|c|}
\hline Company/airline & GER & Executive & Airberlin & 08/12/2011 & $\begin{array}{l}40 \text { min; } \\
\text { telephone } \\
\text { interview }\end{array}$ & $\begin{array}{l}\text { Head of Flight } \\
\text { Operation, } \\
\text { former head of } \\
\text { pilot training }\end{array}$ & $\mathrm{C} / \mathrm{GER} / 7$ \\
\hline Association & $\begin{array}{l}\text { BEL } \\
\text { (Belgium) }\end{array}$ & $\begin{array}{l}\text { General } \\
\text { Manager }\end{array}$ & $\begin{array}{l}\text { Association of European } \\
\text { Airlines }\end{array}$ & $20 / 02 / 2013$ & $\begin{array}{l}15 \text { min; } \\
\text { telephone } \\
\text { interview }\end{array}$ & $\begin{array}{l}\text { Expertise in } \\
\text { FSC and LCC } \\
\text { business } \\
\text { models }\end{array}$ & $\mathrm{A} / \mathrm{BEL} / 1$ \\
\hline Company/airline & $\begin{array}{l}\text { EGT } \\
\text { (Egypt) }\end{array}$ & Executive & Fraport (airport) & $17 / 04 / 2013$ & $\begin{array}{l}60 \mathrm{~min} ; \\
\text { face-to-face } \\
\text { interview }\end{array}$ & $\begin{array}{l}\text { Expertise in } \\
\text { regulation and } \\
\text { strategies in } \\
\text { this industry }\end{array}$ & C/EGT/1 \\
\hline
\end{tabular}


TABLE 3: Important steps in the data analysis process

\section{Methodological Approach}

- Comparative case study approach:

o Comparison of British Airways (United Kingdom) and Deutsche Lufthansa (Germany)

- Key research objectives:

o A: Evaluation and comparison of business models of respective airlines; evaluation to what extent they still represent full-service carriers; identification of business model changes, and typical sequences in business model changes

o B: Evaluation whether employee representation, and potentially supporting institutions, have significantly influenced business model change

- Combination of 'synthetic' and 'narrative' sense-making methods

o Synthetic approach: Definition of clear process boundaries in the form of business model categories, provision of indicators for evaluation business model categories, and identification of business model changes, and typical sequences therein

o Narrative approach: Analysis and comparison of stories in newspaper articles and interview materials concerning the influence of employee representation, and potentially supporting institutions, on business model change (or the lack of it) in each airline

\section{Analysis of secondary data (newspaper articles and annual reports)}

- Synthetic approach

o Selection of passages in identified newspaper articles that were relevant for one or more business model categories; these identified passages were copied into a document for each airline; the documents were structured into years (1993-2013); date, source and relevant business model category were indicated in brackets after the selected passages

o Analysis of selected passages and of annual reports for indicators related to the respective business model categories (example: business model category 'labour costs', indicator: average labour costs per employee; in 2010, for instance, the average labour costs for BA employees were US\$77.000 and those for LH employees \$110.000)

o Identification of business model changes (example: category 'ownership of aircraft' at BA: from $9.9 \%$ leased aircraft in 2011 to $17.1 \%$ in 2012), and typical sequences of changes (LH management acquires airline with lower cost structures 


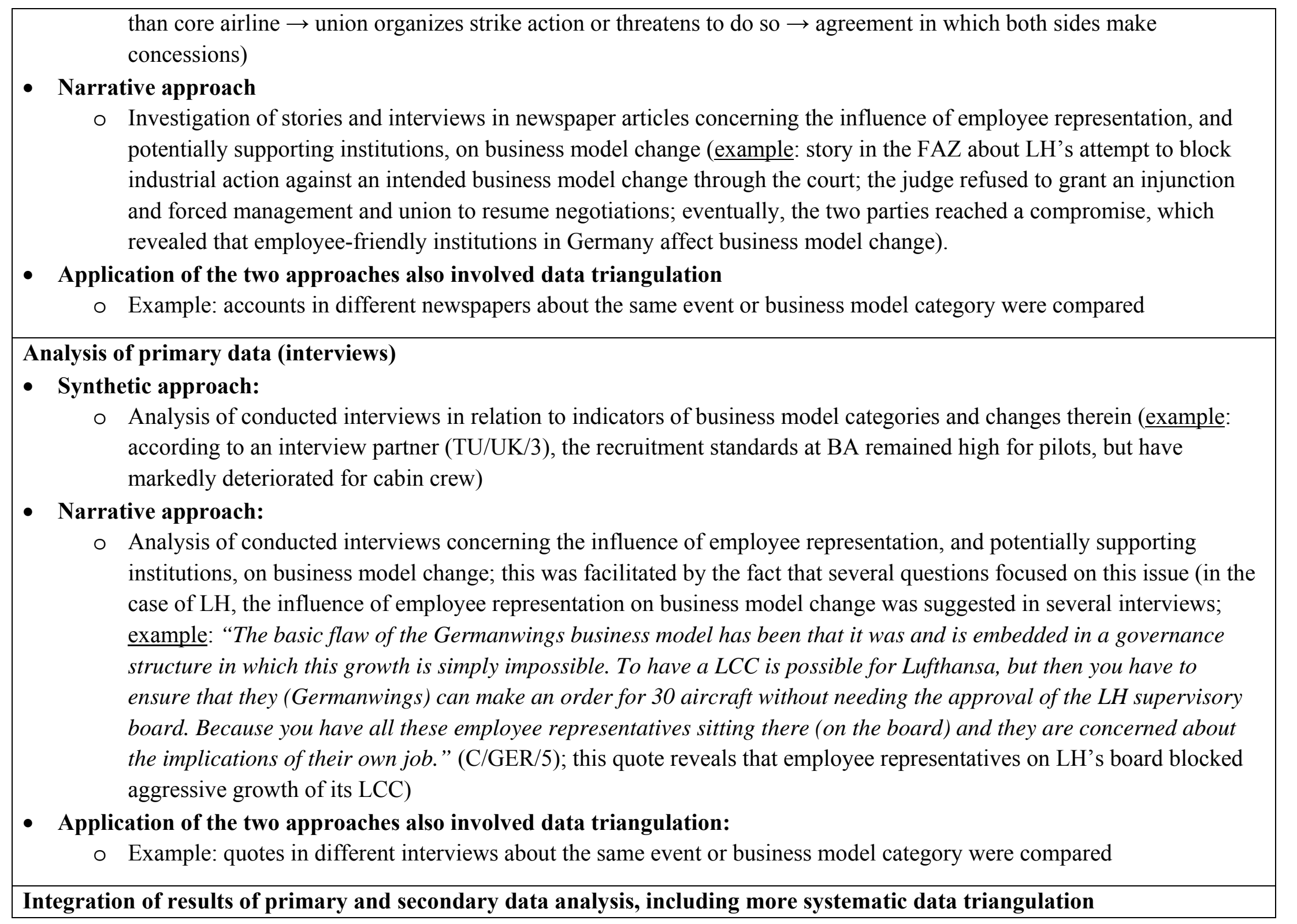


- Key research objectives A (mainly addressed with synthetic approach):

o Evaluation of business models of two airlines based on indicators for respective business model categories: integration of results yielded by the primary (often qualitative) data and secondary (often quantitative) data analysis for all business model categories for each airline (which helped us to make our data more robust);

o Evaluation whether BA and LH still represent FSCs: comparison, based on indicators, of actual business models with ideal type of LCC previously defined

o Comparison whether BA or LH have moved closer to the LCC model, based on indicators for business model categories

o Data triangulation; in case of divergence, which was rare, we relied on the source being closer to the analysed aspect (e.g., the information about the percentage of aircraft leased in the annual report of LH was considered more reliable than the information given by an interviewee who was not directly involved in the financial reporting)

- Key research objectives B (mainly addressed with narrative approach):

o Analysis to what extent employee representation, supported by institutions, influenced business model change: integration of results yielded by the primary and secondary data analysis; this integration of different sources of data allowed us to draw more comparisons between relatively similar attempts of business model change at BA and LH (example: both companies tried to block industrial action, as a result of proposed wage cuts, via court injunction; while BA succeeded (primary data source), LH was not successful (secondary data source) and eventually had to agree to a compromise, which significantly affected the intended business model change; this comparison based on different kinds of data revealed the differential effect of institutions on business model change)

o Data triangulation: (example: triangulation of newspaper reports that LH had co-founded the LCC Germanwings to put pressure on unions with manager interview at $\mathrm{LH}$, which confirmed this point)

Examination of competition as an alternative factor that might have led to differences in business model change between BA and $L H$

- Identification of the role of competition as a potential influence factor on differential levels of business model change in primary and secondary data:

o Systematic analysis of newspaper articles and interviews about relevance of competition as potential influence factor in comparison to strength of employee representation (example: analysis of situations in which LH faced fierce competition but management was not able to change business model significantly due to unions' strength helped to clarify the importance of employee representation as influence factor) 
TABLE 4: A comparison of British Airways and Lufthansa business models in 2012/2013

\begin{tabular}{|l|l|l|l|l|l|}
\hline & $\begin{array}{l}\text { British Airways } \\
(2012 / 2013)\end{array}$ & $\begin{array}{l}\text { Deutsche Lufthansa } \\
(2012 / 2013)\end{array}$ & $\begin{array}{l}\text { Airline closer to } \\
\text { the LCC model }\end{array}$ & Type of choice & Indicators \\
\hline $\begin{array}{l}\text { International } \\
\text { alliances }\end{array}$ & $\begin{array}{l}\text { Leading member of One } \\
\text { World }\end{array}$ & $\begin{array}{l}\text { Leading member of Star } \\
\text { Alliance }\end{array}$ & No difference & Policy choice & $\begin{array}{l}\text { Membership/non- } \\
\text { membership }\end{array}$ \\
\hline $\begin{array}{l}\text { Types of airports } \\
\text { used/ subsidies }\end{array}$ & $\begin{array}{l}\text { Focus on primary } \\
\text { airports (British } \\
\text { Airways, 2012); no } \\
\text { direct subsidies } \\
\text { (C/UK/6) }\end{array}$ & $\begin{array}{l}\text { Focus on primary airports } \\
\text { (Lufthansa, 2012); no } \\
\text { direct subsidies } \\
\text { (C/EGT/1) }\end{array}$ & No difference & Policy choice & $\begin{array}{l}\text { Existence/non- } \\
\text { existence }\end{array}$ \\
\hline
\end{tabular}


Changing Business Models

\begin{tabular}{|c|c|c|c|c|c|}
\hline Labour costs & $\begin{array}{l}\text { Average labour costs per } \\
\text { employee: US } \$ 77.000 \text { in } \\
2010 \text { (FAZ, 2011) }\end{array}$ & $\begin{array}{l}\text { Average labour costs per } \\
\text { employee at Lufthansa } \\
\text { Classic: US } \$ 110.000 \text { in } \\
2010 \text { (FAZ, 2011); } \\
\text { average labour costs of } \\
\text { Germanwings are } 25 \% \\
\text { below those of Lufthansa } \\
\text { Classic (FAZ; 2012b) }\end{array}$ & British Airways & Policy choice & $\begin{array}{l}\text { Average labour } \\
\text { costs per } \\
\text { employee }\end{array}$ \\
\hline $\begin{array}{l}\text { Training and } \\
\text { development of } \\
\text { employees }\end{array}$ & $\begin{array}{l}\text { Investment in training } \\
\text { and development has } \\
\text { been reduced (TU/UK/1) }\end{array}$ & $\begin{array}{l}\text { Investment in training and } \\
\text { development has } \\
\text { remained high }(\mathrm{C} / \mathrm{GER} / 2) \text {; } \\
\text { attempts to reduce } \\
\text { investment blocked by } \\
\text { union (FAZ, 2012i) }\end{array}$ & British Airways & Policy choice & $\begin{array}{l}\text { Qualitative } \\
\text { statements about } \\
\text { areas covered in } \\
\text { training; source of } \\
\text { funding of } \\
\text { training }\end{array}$ \\
\hline
\end{tabular}


Changing Business Models

\begin{tabular}{|c|c|c|c|c|c|}
\hline $\begin{array}{l}\text { Recruitment } \\
\text { standards }\end{array}$ & $\begin{array}{l}\text { Recruitment standards } \\
\text { for pilots have remained } \\
\text { high, but have markedly } \\
\text { deteriorated for cabin } \\
\text { crew in general } \\
(\mathrm{TU} / \mathrm{UK} / 3)\end{array}$ & $\begin{array}{l}\text { Recruitment standards } \\
\text { have remained high; } \\
\text { Germanwings standards } \\
\text { for cabin crew are below } \\
\text { those of LH (TU/GER/1; } \\
\text { C/GER/4) }\end{array}$ & British Airways & Policy choice & $\begin{array}{l}\text { Qualitative } \\
\text { statements about } \\
\text { standards in } \\
\text { comparison to } \\
\text { other airlines }\end{array}$ \\
\hline $\begin{array}{l}\text { Foundation of an } \\
\text { LCC/Size of LCC } \\
\text { fleet }\end{array}$ & $\begin{array}{l}\text { British Airways founded } \\
\text { the LCC Go in } 1998 \text { but } \\
\text { withdrew from this } \\
\text { segment in } 2001 \\
\text { (Guardian, 2006); in } \\
\text { 2011, British Airways } \\
\text { became a branch of IAG, } \\
\text { which also owns the } \\
\text { LCC Vueling }\end{array}$ & $\begin{array}{l}\text { Lufthansa indirectly } \\
\text { founded an LCC in 2002; } \\
\text { Lufthansa wholly } \\
\text { acquired Germanwings in } \\
2009 \text { (FAZ, 2008) }\end{array}$ & No difference & Policy choice & $\begin{array}{l}\text { Existence/non- } \\
\text { existence }\end{array}$ \\
\hline
\end{tabular}


Changing Business Models

\begin{tabular}{|c|c|c|c|c|c|}
\hline $\begin{array}{l}\text { Variety of aircraft } \\
\text { models }\end{array}$ & $\begin{array}{l}12 \text { aircraft models in } \\
2012 \text { (12 models in } 2010 \\
\text { and 2011) (British } \\
\text { Airways, 2012, 2011, } \\
\text { 2010) }\end{array}$ & $\begin{array}{l}18 \text { aircraft models in } 2012 \\
\text { (18 and } 22 \text { models in } 2010 \\
\text { and } 2011 \text {, respectively) } \\
\text { (Lufthansa, 2012, 2011, } \\
\text { 2010) }\end{array}$ & British Airways & Asset choice & $\begin{array}{l}\text { Number of } \\
\text { aircraft models }\end{array}$ \\
\hline $\begin{array}{l}\text { Ownership of } \\
\text { aircraft }\end{array}$ & $\begin{array}{l}\text { 17.1\% of aircraft were } \\
\text { leased in } 2012 \text { (9.9\% in } \\
\text { 2011) (British Airways, } \\
\text { 2012, 2011); } \\
\text { From } 2014 \text { leasing will } \\
\text { become dominant } \\
\text { approach for aircraft } \\
\text { replacement strategy } \\
\text { (Bazargan et al., 2011) }\end{array}$ & $\begin{array}{l}10.2 \% \text { of aircraft were } \\
\text { leased in } 2012 \text { (16.8\% in } \\
2011) \text { (Lufthansa, 2012; } \\
2011) ; \\
\text { CEO announced that } \\
\text { purchase of aircraft is } \\
\text { preferred to leasing (FAZ, } \\
20121)\end{array}$ & British Airways & $\begin{array}{l}\text { Governance } \\
\text { choice }\end{array}$ & $\begin{array}{l}\text { Percentage of } \\
\text { aircraft leased }\end{array}$ \\
\hline
\end{tabular}


Changing Business Models

\begin{tabular}{|l|l|l|l|l|l|}
\hline $\begin{array}{l}\text { Collective } \\
\text { agreements and } \\
\text { their effect on } \\
\text { policy choices }\end{array}$ & $\begin{array}{l}\text { Significant effect on } \\
\text { policy choices ('100 } \\
\text { passenger' scope clause) } \\
\text { (TU/UK/6) }\end{array}$ & $\begin{array}{l}\text { Profound effect on policy } \\
\text { choices (dynamic '95 } \\
\text { passenger' scope } \\
\text { clause/route planning for } \\
\text { foreign subsidiary airlines } \\
\text { severely limited) } \\
\text { (C/GER/2) }\end{array}$ & $\begin{array}{l}\text { British Airways } \\
\text { choice }\end{array}$ & $\begin{array}{l}\text { Constraining } \\
\text { clauses in } \\
\text { agreements }\end{array}$ \\
\end{tabular}

